\title{
HÉT LEHETSÉGES KUTATÁS A TÁRSADALOMTUDOMÁNY MŰKÖDÉSÉRŐL
}

\author{
NAGY PÉTER TIBOR ${ }^{a, b}$ \\ ${ }^{a} E L T E$ TáTK Oktatás- és Ifjúságkutató és Továbbképző Központ \\ 'Wesley Egyház-és Vallásszociológiai Kutatóintézet \\ Beérkezett: 2021. március 31., elfogadva: 2021. október 8.
}

A tanulmány a szerző Négy lehetséges kutatás a felsőoktatókról, című 2007-es írását továbbgondolva háromféle forrásra, s az ezek közötti három különböző fajta kapcsolatokra építő kutatási tervet vázol fel. Az egyik kutatás a pozíciók (bírálati, vezető, beosztotti pozíciók) elemzését végezné el. A másik kutatás a multipozicionalitás hatásait vizsgálja, megkülönböztetve a munkahelyen belüli nem tudományos, munkahelyen kívüli nem tudományos és munkahelyen kívüli tudományos pozíciókat. A harmadik kutatás a folyóiratok világát elemezné, ahogy a többi esetben is megkülönböztetve a folyóiratok irányítását, a folyóiratok publikációra használását, a manifeszt vitát, a lektori aktivitást és a tematikus számok szerkesztését. A „reflexiók” blokkban az idézetek és a kritikák fő funkciójáról a szerző tudományos térben történő pozícionálásáról folytatnánk kutatást. A társszerzőségre vonatkozó kutatás indítóhipotézise szerint három fő motivációja lehet ennek: közös munka, szövetségi viszony és mester-tanítvány viszony kifejezése. A civil szervezeteket, tudományos társaságokat a folyóiratokhoz hasonló módon az irányítók és egyszerű tagként használók kettősségében írjuk le, de itt szerepet kap a írásos világ ellenőrizhetőségétől különböző szóbeliség világa, mely egy külső körnek is utat nyit. A hatalmi erőkifejtés tudományos termeléshez közvetlenül nem kapcsolódó fajtái a pénzosztás, díjak osztása és az adatok birtoklása.

Kulcsszavakः tudományszociológia, felsőoktatásszociológia, elitszociológia, kutatásmódszertan

Continuing the author's 2007 Educatio paper Four Possible Researches on Academic Staff, the study outlines a research plan based on three sources and three different types of relationships between them. The first research would analyzed the positions (exeminer, leader, employed positions). The second research examines the effects of multipositionality, distinguishing the non-scientific positions within academic workplace, nonscientific positions outside academic workplace, scientific positions outside academic workplace The third research would analyze the world of journals, as in the other cases, distinguishing between the management of journals, the use of journals for publication,

Levelező szerző: Nagy Péter Tibor, Wesley Egyház- és Vallásszociológiai Kutatóintézet, 1084 Budapest,

Dankó u. 11. E-mail: nagypetertibor@gmail.com 
the manifesto debate, the lectorship activity, and the editing of thematic issues. In the "reflections" block, we would conduct research on the main function of quotations and critiques on positioning the author in the scientific space. According to the initial hypothesis of co-authorship, there may be three main motivations for this: working together, expressing a covenant relationship, and expressing a master-student relationship. In the chapter of "civil societies" we describe scientific societies in the duality of managers and simple "users", but - contrary to the world of journals - here the non controlled oralism of conferences plays a role, which also opens the way for an outside circle. Types of power effort not directly related to scientific production are the distribution of money, the sharing of medals, and the control over data.

Keywords: sociology of sciences, sociology of higher education, sociology of elites, methodology leírni. (Aronowitz 1988; Barabási 2003; Barnes-Bloor-Henry 2002; Bel 1992; Bourdieu 1988; Bourdieu 2005; Braun 1992; Csomós 2019; Dupcsik 2001; Farkas 1991; Fortescue 1990; Gagyi 2015; Habermas 1994; Horváth 1997; Karády-Nagy 2018; Kováts 2012; Merton 1996; Palló 2011; Papp 2017; Péteri 1998; Püsök 2018; Rácz 2018; Ringer 1990; Szabari 2010; Szelenyi 2015; Tamás 2010; Tamás 1980; Vekerdi 1994.)

1 Részlet egy PhD-hallgató által készített (nem publikált) életútinterjúból, ami szerint kutatói pályám első - Educatio-szerzőségemmel még pár évig átfedő - szakaszában lényegében oktatáspolitika-történeti, második szakaszában alapvetően a társadalmi rétegződés és oktatás történeti kapcsolatát bemutató tanulmányokat írtam - ehhez az utolsó szakaszban társult egyfajta (társadalom)tudomány-szociológiai érdeklődés. Utóbbi objektivációja az Educatióban elsősorban a Négy lebetséges kutatás a felsőoktatókról (Educatio, Vol. 16. No. 3. pp. 434-452. [2007] https://epa.oszk.hu/01500/01551/00041/pdf/389.pdf). Abban az írásban még úgy láttam, hogy külön kellene kutatni 1. az oktatói életrajzokat, 2. azt, hogy hogyan alakítják a felsőoktatásban dolgozók a felsőoktatási szabályozását, 3. az intézmények történetét, és 4. a felsőoktatók szerveződését. Ennek oka az lehetett (ahogyan Csákó Mihállyal egyszer megállapítottuk), hogy bármennyire is konfliktusos paradigmára esküszünk (ill. tudásszociológiai beállítottságúak vagyunk), a funkcionalista megközelítés mégiscsak ott kísért, vagy ahogy a filozófiatörténészek mondhatnák, az „intézmények”, „fogalmak”, „értékek” valós létezéséből kiinduló univerzália-paradigma könnyebben hozza el a hézagmentes magyarázat látszatát, mint az egyének (és a belőlük formált aktorok) cselekvéseit számba vevő nominalista látásmód, ami jelen tanulmányban már győzedelmeskedni látszik: semmilyen társadalmi „dolog”-ról (tehát intézményről vagy kategóriáról) nem mondhatjuk, hogy „valamilyen”, csak azt, hogy benne lévő és vele kapcsolatban álló személyek interakciójában (ill. az egyének cselekvései által) folyamatosan változva alakul.

2 Köszönetet mondok e tanulmány korai változata első kritikus olvasóinak (Biró Zsuzsanna Hannának és Lukács Péternek), valamint Forrai Juditnak, aki a természettudományok történetét hálózatos modelben feldolgozó konferenciára hívott előadónak 2019-ben. A tanulmány előadásváltozatának vitáján Polónyi István hozzászólása és Bazsa György lektori véleménye segített a nyelvhasználatában az intenciónál sokkal inkább hálózatelméletinek tűnő tanulmány elméleti alapjait tudományszociológiai-elitszociológiai irányba átalakítani. 
A legtöbb versengő ${ }^{3}$ analógia - épület, érrendszer, folyók vízrendszere, vallás, háló stb. - nem maradéktalanul jó, hiszen nem veszi be a magyarázatba azt a tényt, hogy a társadalom- és humántudományokkal foglalkozók az elitcsoportok nagy részénél „individualistábbak", ugyanakkor a társadalmi reálfolyamatokra gyakorolt hatásuk magas lehet stb. A más szférák - gazdaság, müvészetek, közigazgatás - egyenlőtlenségeire kidolgozott indikátorok - a vagyon, a jövedelem, a lakóhely, az iskolázottság, a fönöki hatalom, a státuszörökítés, a médiabefolyás mérőszámai stb. - sem kellő mértékben mutatják be a tudományos világ belső erőviszonyait.

Ezért jutottunk arra a meggyőződésre, hogy a tudósok - sokféleképpen, erősen hierarchizált - világát nem különféle indikátorokkal operáló rétegződésmodellel, hanem egy dinamikus mikrotársadalom müködésének leírásával fejezhetjük ki, mely kombináltan alkalmaz elitszociológiai, szervezetszociológiai, tudománymetriai módszereket, prozopográfiát és hálózatkutatást.

Ráadásul a „tudomány világa” ki van téve a társadalmi-gazdasági viszonyok összességének, mármint a „tudomány világát” „eltartó” gazdaságnak és a hálózati működés legfontosabb eszközét jelentő kommunikációt meghatározó jogszabályoknak, a szólásszabadság, a sajtószabadság, az egyetemi tanszabadság mértékének, a közadatok hozzáférhetőségének, a felsőoktatási intézmények szervezeti szabályzatainak, a munkajognak, a közgyüjtemények müködésének, az állami adatgyüjtés rendszerének. Ki van téve továbbá afféle véletleneknek, hogy egy kulcsszereplő mikor hal meg vagy kap valamilyen működését akadályozó súlyos betegséget stb. A tudományos hálózat / tudományos mező számos résztvevője egyénként vagy csoportosan kapcsolatban áll más hálózatok$\mathrm{kal} / \mathrm{mezőkkel,} \mathrm{onnét} \mathrm{szerzett} \mathrm{információit,} \mathrm{befolyását} \mathrm{„tőkeként”} \mathrm{használja} \mathrm{a} \mathrm{tudományos}$ hálózaton/mezőn belül.

E tanulmányban megpróbáljuk megtervezni, milyen dinamikákat tárhatnánk fel a humán- és társadalomtudományok kapcsán a következő években. Noha a tudományágak definíciója maga is egy konstrukció, maga is hálózati kérdés, az adatgyüjtést, elemzést nyilván tudományáganként kellene elkezdeni: ezért, miután - sokféle tudományszociológiai vizsgálódás és persze résztvevő megfigyelés után - végiggondoltuk, hogy a „müködések” milyen típusait kellene feltárni, „esettanulmányként” azt ellenőriztük, hogy a történettudomány vonatkozásában 1980-ra vonatkozó források ${ }^{4}$ és információk ${ }^{5}$ elemzésével a kutatás elvégezhető - s ebből persze az következik, hogy az 1970-re és 1990-re vonatkozó források feltárásával idősorossá is változtatható.

3 Az analóg magyarázatok (piac, színjáték, sportmérkőzés, háború stb.) versengéséről meghatározó olvasmányélményem Kozma Tamás Kié az iskolájának előszava (Kozma 1990).

4 Nagy Péter Tibor A magyar történettudomány 1980-ban - tudományszociológiai elemzés c., készülő monográfia irodalomjegyzékében az 1980-1981-ben publikált viták, konferenciatudósítások, az adtplus. arcanum 1980 és 2000 közötti folyóirataiban szereplő, rájuk történő hivatkozások, valamint a bukaresti történészkongresszusra készített nagyjelentés szerepelnek.

5 Az 1980 körüli történettudományi állapotokról (illetve a társtudományok történetileg releváns munkálkodásairól) szóló 1984 és 2019 között személyesen adott információkért köszönet illeti az alábbi - jó részben már néhai (akiket dőlttel jelzünk) - kollégákat: Ádám Magda, Bányász Rezső, Bokor Péter, Csákó Mihály, Diószegi István, Dóka Klára, Engel Pál, Erényi Tibor, Erös Ferenc, Fenyö István, Forrai Judit, Gergely Jenö, Hajdú Mibály, Hajdu Tibor, Harsányi Iván, Heiszler Vilmos, Huszár Tibor, Jemnitz János, Karády Viktor, Köte Sándor, Krausz Tamás, László János, L. Nagy Zsuzsa, Mann Miklós, Némedi Dénes, Papp Gábor, Pataki Ferenc, Poszler György, Ránki György, Sipos Péter, Standeisky Éva, Stark Antal, Szabad György, Szabó Ágnes, Szabó Ildikó, Szabó Miklós, Szabolcs Ottó, Vámos Éva, Várady László, Vargyai Gyula, Zrinszky László. 
Az alábbi kutatási terv szerint tehát két módszertani megjegyzés után a I-VII. jelzés alatt hétféle tudományos hálózatot/mezőt/jelenséget közel kilencven empirikus változóval látunk leírhatónak. Lásd „A kutatás vázlata” című táblázatot. ${ }^{6}$

\section{A kutatás vázlata}

\section{Módszertani bevezetés}

\section{A megközelítés három szintje}

1. Tudományos produktumok

2. Tudományos intézmények

3. Tudósok élete

\section{A három szint kapcsolata \\ 1.,Minden szinten van adat” helyzet \\ 2.,Egyikben van, másikban nincs” helyzet \\ 3.„Egyik kiegészíti a másikat” helyzet}

\section{A hét kutatás}

\section{Pozíciók}
I.A) Bírálati pozíciók
I.B) Munkahely-irányító pozíciók

lokális; országos; akadémikus vezetőkiválasztás; másodállás; intézményformálódás

I.C) Munkahelyhasználók

\section{A multipozicionalitás hatásai}

II.A) A munkahelyen belüli nem tudományos pozíciók

II.B) A munkahelyeken kívüli nem tudományos pozíciók

II.C) A munkahelyeken kívüli tudományos pozíciók

\section{A folyóiratok}

III.A) Irányító pozíciók

III.B) Használók

III.C) Vita

III.D) Lektorság

III.E) Tematikus számok felsőoktatás-politikai pozíciók; akadémiai bizottságokba kerülés; akadémiai tisztviselőség

monopolfolyóiratok; versengő folyóiratok; aldiszciplináris folyóiratok; intézményi folyóiratok; politikai megosztottság által létrehozott folyóiratok

új eredmények; kötődéskifejezés; nyitottságkifejezés; publikációs hullámok vitacikk; szerkesztőségi kommentár; vita a szerkesztőbizottságban; viszontválasz

6 Nem szeretném a teljes szisztematikusság látszatát kelteni, de elfogadtam Bazsa György tanácsát, hogy egy 88 kritériumból álló szöveget mégiscsak előzzön meg valamiféle vázlat. 
A kutatás vázlata (folyt.)

\begin{tabular}{ll}
\hline $\begin{array}{l}\text { IV. Reflexiók } \\
\text { IV.A) Kritika }\end{array}$ & $\begin{array}{l}\text { felkért/jelentkező recenzens; ismertetö/érdemi } \\
\text { kritika; minőség; teljesség } \\
\text { méret és gyakoriság; megemlítés; köszönet; } \\
\text { inadekvát idézet }\end{array}$ \\
IV.B) Idézet & \\
\hline V. Társszerzőség & \\
V.A) Közös adatgyüjtések & \\
V.B) Szövetségi politika & \\
V.C) Mester-tanítvány & operatív/szimbolikus társasági funkciók; alcsopor- \\
\hline VI.„Civil” szervezetek & tok; új társaság alapítás; konferenciatémák \\
VI.A) Irányítók & tagság; csoporttagság; jelenlét; elöadásvállalás \\
VI.B) Használók & \\
VI.C) Tágabb kör &
\end{tabular}

VII. Egyéb hatalmi hálózatok

VII.A) Pénzosztás

döntéshozó; ajánlás; skála

VII.B) Díjak

VII.C) Adatbirtoklás levéltár; statisztika; közvéleménykutatás;

digitalizáció; emlékezet

\section{A megközelítés három szintje}

Ha ma bármelyik bölcsészettudomány, társadalomtudomány összefüggésrendszerét le akarjuk írni, akkor a legfőbb célunk három „szint” elkülönítése.

1. Az egyik „szint” a tudományos produktumokra vonatkozó információk. A tudományos produktumok lehetnek publikált és nem publikált tudományos írások, kutatási jelentések, adatbázisok, egyetemi és konferencia-előadások, szakértői tevékenység, televízió- és videóanyagok, internetes bejegyzések stb. A müfajok sokfélesége empirikusan megnehezíti a különböző tudományágak - ezen belül pl. a történettudomány egyes korszakaira orientált kutatók életművének - összehasonlítását, sőt egyetlen tudományágon belüli idősoros elemzést is. Ezért - legalábbis azoknál a kutatásoknál, melyek több tudományágról is kívánnának szólni, vagy amelyek nem szükítik a vizsgálatot a 2010-es és 2020-as évekre - empirikusan összehasonlítható tudományos produktumként a publikált szövegek (írások, fordítások, szerkesztések, dokumentumpublikációk) számbavételét tartjuk célszerünek, így az 1980-as történettudományi példaelemzés esetében is. (Ami természetesen nem menti fel az elemzőt az alól, hogy elemezze, hogy a klasszikus publikációk relatív súlya az egyes csoportok közötti különbözőséget tekintve és az időtengelyen hogyan változik az egyetemi előadásokban, szabadegyetemen, ellenzéki repülö egyetemen, könyvtári/kávéházi/kocsmai beszélgetésben létrehozott „szóbeli életműhöz" 
képest. Az ezredforduló kutatója a tömegkommunikáció, napjaink és a jövő kutatója az internet felületeihez képest kell, hogy meghatározza a nyomtatott publikációk súlyát.)

A tudományos produktumok legfóbb forrásai a személyi bibliográfiák (a 2010 utáni évtizedben aktív magyar kutatókra nézve az „mtmt”) vagy a megjelent könyvek bibliográfiája, a nemzeti könyvtár katalógusa ${ }^{7}$, illetve a "matarka” cikkatalógusa. A szakbibliográfiák már ellentmondásos források, hiszen a szaktudomány centruma felől nézve „tudományon kívüli” írások szisztematikusan kimaradnak.

A kimaradásnál két - egymástól független - jelenségről van szó. Az egyik, hogy a hétköznapi nyelven áltudománynak tekinthető publikációs aktivitás aktorai (pl. a lapos föld elmélet hívei, a Holokauszt-tagadók, a Jézus Krisztus magyar származását vallók stb.) a tudomány funkcionalista-normatív önképe szerint nem valók tudományos bibliográfiába, tudományszociológiai értelemben viszont a tudományos erőtérhez tartoznak, tehát számba veendők (Bourdieu 2005).

A másik, hogy vannak olyan más szellemi területen tényleg elismert értelmiségi alkotók, akik a „céhen” kívül maradva írnak tudományos vagy népszerűsítő életrajzokat írókról, művészekről, hadvezérekről és politikusokról - semmiféle irodalomtörténeti, művészettörténeti, hadtudományi vagy politológiai bibliográfiába be nem kerülve, vagy sikeres újságíróként kötetnyi terjedelemben elemzően bemutatnak külföldi vagy nemzetközi jelenségeket anélkül, hogy egyetemes-történeti, politikatudományi, közgazdaságtudományi bibliográfiákba kerülésre aspirálhatnának. Ha ezeket nem vennénk számba, úgy járnánk el, mintha az irodalomtudomány egy korszakot csak a megszületett művekkel jellemezne - s ügyet sem vetne az olvasókra.

2. A másik „szint” a tudományos intézmények adattömege, folyóiratok, tudomány-népszerüsítő rovatok, könyvkiadók, tudományos társaságok, főiskolák, egyetemek, tudományos intézetek, társadalmi szervezetek tudományosnak vagy tudomány-népszerűsítőnek értelmezhető részlegei, tudományos pályázatok, tudományos eszközöket használó (és tudományosan használható adatokat termelő) közvéleménykutató, piackutató, politikai tanácsadó cégek, államigazgatási, önkormányzati, törvényhozási, bírósági szakértői tevékenység... (Nyilván a piaci intézmények az 1980-as magyarországi történettudományra vonatkozó vizsgálat esetében nem relevánsak, bár tudományos munkaerőpiacról, kiadók részben piaci versengéséről már beszélhetünk).

Ezeknek az intézményeknek az adatai, ha eltérő részletezettséggel is, több tudományág vonatkozásában, több időpontra rendelkezésre állnak. A tudományos élet sajátosságainak megfelelően minden intézményesülési formánál a kutatás szempontjából „irányító”-nak nevezett, a kutatás szempontjából „használó”-nak nevezett pozíciók elkülönítése lehetséges. Ugyanis szempontunkból nem az a lényeg, hogy ki vezető és ki beosztott, ki önkéntes és ki fizetett alkalmazott, hanem az, hogy a tudós az adott intézményt irányitja vagy használja céljai elérése érdekében. (Itt természetesen nem számít, hogy egy beosztott munkavállaló nem feltétlenül éli meg úgy, hogy ő használja a munkahelyét, sőt lehet, hogy úgy látja, a munkahely használja őt. Vannak ugyan élethelyzetek, amikor egyének ismertsége, tőkéje magasabb az őt foglalkoztató intézményénél, mégis a tipikus helyzet az, hogy az egyéni tudós hitelességét növeli - különösen, hogyha

A kettő azért különbözik, mert az OSZK katalógusába bekerülnek magyar tudósok nem „Magyarországon" - értsd: magyar ISBN kóddal - megjelent könyvei is. 
szűkebb szakterületén kívülről ítélik meg -, hogy neve mellé, alá odakerül, neve elhangzásakor beasszociálódik valamilyen intézmény neve.) Az egyén tehát - ha tudatosan, ha nem - intézmények tekintélyét kölcsönzi saját céljaihoz.

A legkülönbözőbb intézményesülések lehetővé teszik összegekben, példányszámokban, megjelenési gyakoriságban, terjedelemben, létszámokban, százalékos támogatottságban stb. kifejezhető nagyságrendek elkülönítését, azaz - kódolási szempontból - skálázását vagy legalábbis afféle beosztását, hogy átlag alatti, átlag körüli, vagy átlag feletti tevékenységről van szó, időtengely esetén csökkenő, szinten maradó vagy növekvő szerepvállalásról stb.

E szinthez olyan források tartoznak, mint az egyetemi évkönyvek, az akadémiai almanachok, a folyóiratok kolofonja, az „e számunk szerzői” rovatok a folyóiratokban, a tudományos társasági ülésekről, akadémiai bizottsági-albizottsági ülésekről, kandidátusi, nagydoktori védésekről, konferenciákról szóló beszámolók a folyóiratokban, az egyetemi tanári kinevezésekről, állami kitüntetésekről szóló tudósítások, közlemények a közlönyökben, illetve olyan sorozatszerüen meglévő levéltári források, mint egyetemi tanácsi, kari tanácsi előterjesztések, egyetemi, kutatóintézeti bérlisták. ${ }^{8}$

3. A harmadik „szint” a tudományos mezőben jelen lévő személyek saját története itt a szociológus számára azok a források jönnek szóba, melyekről feltételezni lehet, hogy a beválogatott személyekröl valamiféle szisztematikussággal közölnek adatokat. Mindenekelőtt a lexikonok személyi szócikkei tartoznak ide, valamint az élő hírességekre, halott hírességekre, egy-egy földrajzi terület híres szülötteire koncentráló életrajzgyüjtemények. (Az 1980-as történettudomány esetében elsősorban a legújabb Magyar életrajzi lexikon ${ }^{9}$, illetve az 1980-as, 1990-es, 2000-es évek Ki Kicsodái.) Természetesen használhatók az akadémikusokra, professzorokra, egy-egy tudományterület nagyjaira vonatkozó gyüjtemények is, de utóbbiak esetében tudnunk kell, hogy az adott tudományág „normál” működésében szokásos adatokat felülreprezentáltan, a szokatlan adatokat viszont alulreprezentáltan fogják a tudóséletrajzok adni, s bizonyosan kimaradnak olyan életrajzok, melyeket akár tudományos produktumok, akár az intézmények felől gyüjtött személylisták alapján fontosnak tarthatnánk, de az adott tudományág vagy egyetem kézikönyvét kiadó tudományos csoport szemében tudományon kívülinek minősülnek.

A személyi címszavak, életrajzi lexikonok, who is whok elsősorban a születési helyek és időpontok, halálozási helyek és időpontok rekonstrukciója szempontjából „objektívek" - ezenkívül az egyetemi tanulmányok rekonstruálhatók a legnagyobb biztonsággal, az életutakról, kitüntetésekről, külföldi kapcsolatokról, elnyert pályázatokról szóló adatok már tudatosan formált narratívák, ha tömegesen nem is hamisak, de mindenkinél válogatottak. (Az egyik legfontosabb tapasztalat, hogy amikor folyóiratok „tudományos hírek”, vagy „nemzetközi kapcsolatok” rovatai alapján az átlagnál háromszorötször gyakrabban külföldre járó csoportot meghatározzuk, majd külföldi utakról szóló

\footnotetext{
A levéltári források feldolgozását még meg sem kezdtük.

9 Mármint azokra, akik az 1990-es második pótkötet lezárásig, illetve a 2001-s Új magyar életrajzi lexikon (főszerk. Markó László) lezárásáig hunytak el. Bár napjainkban folyamatosan bővülnek az életrajzi portálok, Karády Viktorral közös reputációs elitkutatásaink során arra a meggyőződésre jutottunk, hogy a fix időponthoz, kiadóhoz, terjedelemhez kötött nyomtatott források - ez esetben éppen zártságuk miatt - kevésbé kiszolgáltatottak az „inflációs” hatásnak.
} 
említéseket a személyi címszóban megszámoljuk, úgy tűnik, mintha a csoport előnye legfeljebb másfélszeres lenne. Azaz a lexikonszerkesztés gyakorlata a gyakran külföldre járók esetében a legfontosabb külföldi utak megemlítésére korlátozódik. Hasonlóképpen a nemzeti bibliográfiák tanúsága szerint 10-nél több könyvet publikáló szerzőknél lexikoncímszavuk éppúgy öt könyvet sorol fel, mint az ötkönyves szerzők esetén, tehát a „felsorolt könyvek száma” esetében csak hat kategóriát enged - mármint ha a szerzők termékenységét a lexikoncímszó és nem a nemzeti bibliográfia adatai alapján soroljuk be. A lexikonok által megemlített munkahelyek viszont az egyéb forrásokból rekonstruálható munkahelylistától csak csekély mértékben térnek el.)

\section{A három szint kapcsolata}

A háromféle adatgyüjtés - ahogyan az előző fejezet végéből már sejthető - gyakran ugyanazokról az emberekről hoz adatokat. A három szint három különböző módon vonatkoztatható egymásra:

1. Optimális esetben az adattárak összekapcsolhatók, mégpedig többféle módon: legkézenfekvőbb a személyek nevét használni kapcsoló változónak, de időpontok, kulcsszavak, intézménynevek kapcsolónak használatával részproblémák megértését támogató adatbázis-variációk készítése is történhet.

2. A részleges hiány ez esetben jelentésteli! Megállapítható, hogy

- a társadalomtudományi (ilyen folyóiratban megjelent, könyvtárosok által ETO besorolással ilyennek minősített) művek szerzői mely esetekben nincsenek jelen a tudományos intézményrendszerben, illetve

- mely esetekben nem érik el az ismerendőségnek azt a mértékét, ami lexikonba kerüléshez vezet;

- megállapítható, hogy az intézményrendszerben felbukkanó (a tudományos káderpolitika által tehát fontosnak, legitimnek tekintett) személyek mely esetekben nem rendelkeznek nyilvános tudományos életmüvel, illetve

- ugyanezek a személyek mely esetekben nem érik el az ismerendőségnek azt a mértékét, ami lexikonba kerüléshez vezet; s végül, hogy

- kik azok az egyéb (nem tudományos, hanem pl. politikai vagy média) okoknál fogva neves személyek, akikkel kapcsolatban a lexikon fontosnak tartja megemlíteni, hogy eredeti foglalkozását tekintve pl. történész vagy közgazdász - miközben ennek sem a bibliográfiákban sem a tudományos intézményeknél nincsen nyoma.

3. Elképzelhetö, hogy az egyik típusú forrást a másikfajta forrás kiegészitésére vagy kiváltására is használhatjuk. Ha azt mondjuk, hogy meghatározott tudományág intézményes viszonyait egy meghatározott évtizedre nézvést kifejezetten gyengén tükrözik a források, viszont egy évtizedekkel későbbi (történeti vagy kortárs) életrajzi lexikon szisztematikusan feltünteti a tudományos pozíciókat, akkor eljárhatunk úgy, hogy meghatározott korszak tudományos pozícióinak rendszerét az életrajzi lexikon által különböző életrajzoknál közölt adatokból rekonstruáljuk, abból a feltevésből kiindulva, hogy a fontos pozíciókat betöltő személyek általában bekerülnek a későbbi lexikonokba, s a lexikonszócikkek szerzői csak kis eséllyel engedik meg maguknak, hogy - ha már egy 
személy bekerüléséröl döntés született - az általa egy meghatározott időszakban betöltött fontos pozíciót nem említik meg. (Ha például valamely tudományág egy meghatározott évtizedben „nem létezik” önálló tudományágként - a tudomány későbbi tudósainak az adott időpontra vonatkozó munkahelyi adatai eligazítanak -, ha máshonnét nem, ezen a módon tudomást szerezhetnénk pl. a KSH könyvtárának szerepéről a szociológia 50-es évekbeli átmentésében. ${ }^{10}$ ) Ez az adatpótló hatás - valószínűségi alapon - még a publikációkra is igaz: pl. ha meghatározott könyvsorozat szerkesztőbizottsága szinte kizárólag olyan szerzőket hívott meg, akik tudományos pozíciót töltenek be, illetve akik életrajzukkal bekerültek a lexikonokba, akkor az adott könyvsorozat szerzői köréhez tartozást akkor is elitbe tartozás jelzésének nyilváníthatjuk, ha az intézményes listán való nem szereplés, lexikonban való nem szereplés okán ezt - az adott személlyel kapcsolatban - nem tehetnénk.

Mindezen források bázisán a tudományszociológiai kutatások több fajtája lehetséges.

\section{Pozíciók}

I.A) A tudományos hierarchia bírálati pozícióinak léte és müködése teszi a tudományt komplikáltabbá, mint azokat az alrendszereket, ahol a személyeket egy meghatározott pillanatban egyértelmúen főnöknek vagy beosztottnak, gazdagnak vagy szegénynek, iskolázottnak vagy iskolázatlannak minősíthetjük. Ugyanis a bírálati pozícióval átmenetileg „irányítóvá” válik egy fö szabályként „használó” személy.

I.A)1. Ezen pozíciók között vannak lokális jellegűek, ilyenek az államvizsga-bizottságok tagjai, a doktori folyamatok aktorai - 1993 előtt a dr. univ. bizottságok tagsága, 1993 után a PhD-iskolák bírálói pozíciói, s a habilitációs bizottságok tagi pozíciói. Ha a tudományt valamennyire is zárt rendszernek látjuk, a hálózat belépési pontjain ők a „kapuörök”, de „örködésük” semelyik tudományágban nem lehet standard: történettudományban pedig különösen jellemző, hogy minden egyetemnek saját doktori erőtere van. Az adott egyetemen nem tanító külső bizottsági tagok, opponensek e sajátosságokat mérséklik, de el nem tüntetik: az 1980 körül ilyen szerepet játszó történészek többségére igaz, hogy esettanulmány-szinten igazolható módon alkalmazkodtak a helyi sajátosságokhoz.

I.A)2. Országos jellegü pozíciók 1950 és kb. 1998 között a kandidatúra bizottságok, 1950-től napjainkig a nagydoktori bizottságok - s ezekben a bizottságokban az elnöklés, opponencia, tagság. Ezeket a pozíciókat az országos tudományos hierarchiában bizonyos elismertséggel (s semmiképpen csak helyi legitimációval) rendelkező személyek töltik be. Bizonyítható, hogy a szükebb témában jártas, de alacsonyabb általános legitimációjú bizottsági tagok számát mindig meghaladja a magasabb általános legitimációjúaké, s az elnökök között szinte mindig magasabb legitimációjúak vannak. (Ezért fordulhat elö, hogy a szükebb témájukban erős, azaz sok lektorált cikket publikáló szerzők a tudományág „általánosabb szempontjait” alkalmazó minősítési folyamatban gyengén szerepelnek.)

10 Mely egyébként olyan fontos, hogy a magyar szociológia történetének megszakítottságáról szóló, széles körben elterjedt álláspontot Csákó Mihály egy előadásában épp erre hivatkozva kétségbe is vonta. 
I.A)3. Az első két pontban jelzett (nem formálisan vezető, de a rendszert irányító) pozíciók olyan folyamatok kimenetelének elbírálására jönnek létre, melyet a tudósok saját karrierjük vonatkozásában maguk kezdeményeznek. Más jellegű az akadémikusok jelölésének processzusa, ez az egyén által nem kezdeményezhető forma, az akadémia tagjainak döntésén alapul - amit megelőz az akadémiai osztályhoz tartozó akadémikusok arra irányuló döntése, hogy mely tudományág képviselője töltse be a megürült akadémiai pozíciót. A humán- és társadalomtudósok az I., II., IX. osztály tagjai, ${ }^{11}$ de minden osztály több, egymástól teljes mértékben elkülönült tudományág képviselőit tömöríti, s nincs elvi szabály arról, hogy x tudományág képviselőjének elhalálozásakor feltétlenül ugyanazon tudományág képviselőjét kell meghívni, tehát ez is erőviszonyok, alkuk tárgya. Tudunk rá példát, hogy elhalt szociológus helyét közgazdász beválasztásával töltötte ki az osztály, de tudományágon belül is előfordulhat, hogy nem egyének versengése, hanem részterületek - tudományon kívüli okokkal magyarázható - versengése dönti el akadémiai helyek sorsát, például (rendszerváltás előtti történettudomány mezőjében gondolkodva) ha a tudománypolitika a Szovjetunió történetének, a nemzeti függetlenségi harcok történetének vagy a vallások történetének akadémiai „képviseletét” látja „gyengének.” (A valóságban nem képviseletről van szó, hiszen nem a tudományterület minősítettjei, hanem az akadémikustársak hoznak arról döntést, kit hívnak meg tagnak. Gyakorlatban persze csak a nagydoktori fokozattal rendelkezők közül választanak.) Jól látható, hogy vannak olyan akadémikusok, akik gyakrabban, és vannak, akik ritkábban élnek a tagajánlás jogával - ennek alapján a bírálati pozíció a legfelső szinten is értelmezhető. Mivel több akadémikus ajánl egy-egy személyt, az ajánlási aktus maga kvázi-érdekcsoportok koalíciójaként értelmezhető.

I.B) A tudományszociológia nagy és fontos témája, hogy egyes vezető tudósokat mely munkahelyekhez lehet kötni, kinek hol, mekkora másodállása, harmadállása van. Három különböző kérdést vizsgálhatunk:

I.B)1. A meglévő pozíciókat (pl. azonos profilú tanszékek vezetői pozícióit) egy szakma elitje mintegy elosztja egymás közt. (Miközben a formális döntést egy konkrét egyetem más tudományágak képviselőiből álló kari tanácsa hozza meg, számos visszaemlékezés bizonyítja, hogy pl. a történész tanszékek vezetésének 1980 körüli megpályázását a szakma országos tekintélyei közötti konzultáció előzte meg.)

I.B)2. A másodállások, harmadállások biztosításával az elit tagjai kölcsönös szívességi rendszerben kisegítik egymást, álláshalmozással küzdve le azt az akadályt, hogy egy tudományágon belül valakinek a „kvázipiaci” pozíciója erősebb, mint amennyire egy munkahelyen belül, közalkalmazotti, akadémiai bértábla által szabályozott jövedelme megemelhető. Ugyanilyen fontos, hogy a hálózatszerűség sajátos kölcsönösséggel biztosítja azoknak az etikai szabályoknak a megkerülését is, ami a házastársak, titkos

11 Tárgyi kivételt képeznek az alapvetően természettudósi orientáltságú Földtudományi osztály társadalomföldrajzos tagjai, illetve a természettudományi és élettudományi - igen ritkán műszaki - osztályok azon tagjai, akik - általában már akadémikussá válásukat követően - az adott tudományterület történetével, és/vagy társadalmi kontextusaival kezdenek foglalkozni, gyakran nagyobb közéleti hatást gyakorolva, mint a bölcsész vagy társadalomtudományi színekben felemelkedett kollégáik. 
kapcsolatok, rokonok, szerzőtársak alkalmazása ellen szólnak. A jövőbeni viszontgesztusokkal kapcsolatos informális elvárásrendszer lehetővé teszi, hogy egy vezető tudós jelöltjei akkor is tudományos álláshoz jussanak, ha a vezető tudós konkrét rendelkezési körében éppen nincs szabad állás. (Az egyetemi évkönyvek erre szisztematikus forrást nyújtanak, s az MTA intézetek személyi viszonyairól a kutatás elején létrehozandó adatbázis kiegészítheti ezt.)

I.B)3. E müködésnek intézményformáló hatása is van, amennyiben nagyobb tanszékeken belül részlegek, csoportok kifejezetten azért jönnek létre, hogy egy vezetői pozícióért történő versengésben alulmaradt személyt kárpótoljanak, vagy hogy az életkori okokból lemondásra, újra nem pályázásra kényszerült vezető kutató és az új főnök békés egymás mellett élését azzal biztosítsák, hogy az alulmaradt, lelépett személynek valamifajta „saját tartománya” lesz a tanszéken belül. Évek múltával a személyi kontextus már elenyészik (pl. az érintett személy meghal), de az önálló szervezeti alegységek - a szervezetszociológia törvényszerűsége szerint, a korábban odakerült vagy éppen az elhunyt egykori vezetőhöz szorosabban kötődő tudósok érdekvédelmeként is értelmezhetően saját maguk fennmaradásában érdekelve vesznek részt a tudománypolitikai mezőben folyó küzdelmekben.

I.C) Természetesen nemcsak a vezető kutatók, hanem a beosztott kutatók (a „használók") is részt vesznek a tudományos erőviszonyok alakításában munkahelyük megválasztásával, ill. azzal, hogy hová adják tudományos „vegyértéküket”, azaz a tudományos munkásságukból, tudományos fokozatukból következő előnyöket mely intézmény munkásságához lehet hozzászámolni.

Számos társadalom- és humántudományi szakember tényleges tudományos teljesítménye valójában individuális - az alapvetően ténylegesen csoportban dolgozó, illetve jelentős dologi-költség igényü természettudósokkal, orvostudósokkal szemben - „vegyértékük hova adásának” kérdését nem a munka tényleges „helyszíne”, hanem a szóba jövő, a tudós vegyértékéért versengő intézmények presztízse, meglévő személyi viszonyai, az általuk előteremthető bértömeg, az odaítélhető pozíció és a munkafeladatokkal kapcsolatos informális megállapodás befolyásolja. Az életrajzokból és az egyetemi évkönyvekből egyaránt igazolható jelenség, hogy formálisan azonos, azaz egyetemi szintü tanszékek között szisztematikus mozgás van: Budapeströl vidékre, nagyobb hagyományokkal rendelkező tanszéktől fiatalabb tanszékre történő mozgás majd mindig docensből professzorrá válással jár együtt. Sőt fordított mozgás is vanः vidéki docensek számára gyakran „megéri” adjunktusi kinevezést szerezni Budapesten.

\section{A multipozicionalitás hatásai}

II.A) Fontos változóként vehetjük fel, hogy a tudós az egyetemen vagy kutatóintézeten, azaz saját munkabelyen belül milyen nem tudományos pozíciókra tett szert. Az 1948 és 1989 közötti világban a párt, a KISZ, a szakszervezetek szigorúan munkahelyi alapon szerveződtek, s tisztségviselőiknek formálisan is jelentős befolyásuk volt a helyi ügyekre, a 80-as évektől napjainkig igaz, hogy a hallgatói és oktatói csoportok vezetői informálisan, a kari, egyetemi tanácsok választott tagjai, hallgatói képviselői, különféle 
célokra szervezett egyetemi bizottságok tagjai pedig formálisan is befolyással vannak az egyetemi ügyekre.

A visszaemlékezések felhasználásán túl itt más objektiváció is lehetséges: ha akadémiai elismertségük mértéke szerint sorba állítjuk egy-egy tanszék, egy-egy tudományág képviselöit, gyakran tapasztalhatjuk, hogy ezeknek a nem tudományos pozícióknak a betöltői a pozíció betöltésének kezdetekor hátrább vannak a sorban, mint a nem tudományos pozíciójukból való kilépéskor, annak ellenére, hogy a nem tudományos pozícióval járó elfoglaltság nyilvánvalóan csökkentette az akadémiai tevékenységekre fordítható időt és energiát.

A jelenséget nem értelmezhetjük másképp, minthogy a pozícióban lévő személy tervezetten vagy tervezetlenül, durva vagy finom eszközökkel - szívességeket tett akadémiai értelemben erősebb kollégáinak, erősítette kapcsolati hálóját. Az ilyen módon felhalmozott tőke azután később akadémiai fokozatok átlagosnál könnyebb, sőt egyes esetekben a "kívülállók” (paradox módon épp a leginkább bennfentesek leplezik ezt le) szemében érthetetlen, sőt korrupciógyanús megszerzésében kamatozhatott. Bizonyos - utólagos - pozícióelmozdulásokat, „hasznokat” - pl. MTA-taggá válást, régen hiányolt szervezeti egység megteremtését - még azoknál a személyeknél is konstatálhatunk, akik látszólag a „csúcson”, azaz professzorként választattak dékánhelyettessé, dékánná, rektorhelyettessé, rektorrá. Az egyetemi pozíciók - mivel a bölcsészkarok talán legnagyobb alnépessége a történésznépesség - igen sok történészt érintenek, tehát sokkal szisztematikusabban hatnak vissza a tudományág belső erőviszonyaira, mint kis tudományágak esetében.

II.B) Munkabelyeken kivüli nem tudományos pozíciók elvállalása a tudományos mezőn belüli pozíciót mindenképpen erősíti. Egy-egy tudományág képviselőjének jelenlétét az üzleti (1980 tájbanः gazdaságigazgatási) szférában, a törvényhozásban, az állampárt (vagy 1990 után politikai pártok) vezető elitjében, a politikai sajtóban, az államigazgatásban az akadémiai közösség hajlamos úgy tekinteni, mintha az illető valóban a „szakma” kép viselöjeként lenne jelen pozíciójában. Ismeretségre, kollegialitásra hivatkozó segítségkérés gyakoriságát szakmapolitikai, sőt magánügyekben a közéleti pozícióhoz jutott tudósok, egyetemi oktatók akkor is gyakran tapasztalják, ha a segítségkérő - a tudományágon belüli csoport-hovatartozás szerint vizsgálva - semleges vagy akár konkurens, ellenséges csoporthoz tartozott. Ennek viszont az a következménye, hogy a közéleti pozíció nem egyszerűen megerősíti a tudós meglévő pozícióját, hanem újabb, tudományon belüli hálózatok részévé is teszi őt - közéleti pozícióban tett szívességeivel olyan kollégáitól is viszonzást várhat a tudományos életbe való visszatérése után, akiket tudományágon belül korábban ellenfelének tekinthetett.

II.C) Munkahelyeken kivüli tudományos pozíciók megszerzése másképpen érinti a tudós helyzetét.

II.C)1. Régebben a minisztériumok, ill. pártközpont felsőoktatás-politikai pozíciói, 1993 után a MAB szakakkreditációs, intézményakkreditációs tevékenységben való részvétel erősen megemeli a tudós multipozicionalitásából eredő tőkét. A tudós garantáltan nem vesz részt saját kenyéradó intézményének, ill. azon belül saját szakjának akkreditációs, engedélyezési folyamatában, viszont egészen pontosan látja, hogy kik vesznek részt 
abban, s egészen pontosan tudhatja, hogy hamarosan ő lesz abban a helyzetben, hogy e résztvevők, mint kollégák és konkurensek számára fontos akkreditációs, engedélyezési folyamatra befolyása legyen. Tehát míg az akadémiai nyilvánosság egészében a kölcsönös támogatások/akadályozások rendszere nélkülözi azt a bizonyosságot, hogy a tett ( $\mathrm{pl}$. opponensi értékelés, kritika, állásajánlás) ténylegesen „meghálálásra” vagy „megboszszulásra" kerül, a felsőoktatási ügyosztályon vagy a MAB-on belül ez - vagy legalábbis ennek kínálkozása - kétségtelen. Másrészt a felsőoktatást felügyelő kormányszerv, ill. a MAB munkájában részt vevő tudós számtalan kapcsolatot épít saját tudományágában, befolyását tehát nemcsak saját intézménye érdekében tudja hasznosítani, hanem személyes karrierjét is nagyobb eséllyel tudja - intézményváltással vagy az intézményváltás lehetőségének saját intézménybeli érzékeltetésével - elősegíteni, mint részt nem vevő kollégája.

II.C)2. Az akadémiai bizottságokba kerülés másféle aktivitást feltételez. Vagy arra van szükség, hogy a tudós a saját tudományterületén belül az egyik részterület követőinek képviselöje, egyik paradigma követőinek elfogadott képviselöje legyen, vagy arra, hogy egy-egy intézmény adott tudományágbeli tudósközössége képviselőjének tekintse őt. Tudatos jelölések, tervezett visszalépések befolyásolják ezt a folyamatot. Kivételt azok a jelöltek képezhetnek, akik központi intézményekben dolgozva sok köztestületi tag „kedvelt tanára”, „szellemi példaképe” szerepet töltenek be, ők a nem stratégikusan alkalmazott (mondjuk: értékelven vagy ízlésítéleti elven leadott) szavazatok haszonélvezői. Az akadémiai bizottsági tagok vélelmezett (vagy kifejezett) választóik támogatását többféle módon viszonozhatják: az MTA doktori habitus elbírálásakor vállalhatnak bírálói szerepet, vagy legalábbis szavazhatnak úgy, ahogyan az „választóik” érdekében áll, befolyásolhatják, hogy az akadémiai doktori bizottságokba kiket kérnek fel, illetve - legalábbis egyes bizottságoknál - alakíthatnak tudományterületek, tudományrészek szerint szerveződő albizottságokat, ahova felkéréssel hívhatják meg minősített kollégáikat.

Ellentétben az állásosztogatással vagy a pályázatok osztogatásával az albizottsági tagmeghívásoknak költségvetési korlátja nincs, hiszen e pozíciókat a tudósok ingyen - szimbolikus tőkéjük növelése érdekében - töltik be. Van viszont „inflációs korlát” egyes akadémiai ciklusokban megszűnnek, más ciklusokban újranyílnak a tudományterületi albizottságok épp azért, mert az albizottságokat működtetők ellenérdekeltek abban, hogy mások újabb albizottságokat alapítsanak, s ezzel az általuk birtokolt, illetve általuk kiosztható pozíciók exkluzivitását csökkentsék. Mi több, időnként az albizottságokat nem müködtetők is érdekeltek lehetnek abban, hogy másoknak se legyen albizottságuk, hiszen ez - az egyébként azonos „rangú” tudósok között - presztízselőnyt biztosít.

Választott köztestületi képviselők jóval kevesebben vannak, mint tudományos bizottsági tagok, tehát míg a bizottsági tagsághoz egy tudományág egy csoportjának a szavazatait elegendő megszerezni, a választott képviselőnek szélesebb körű elismertségre van szüksége.

II.C)3. Az akadémiai tisztviselőség - osztályelnök, alelnök - megválasztása megint másféle aktivitást feltételez, hiszen az ezzel kapcsolatos tárgyalásokban a tudomány- 
ágakon átívelő, sőt tudományágcsoportokon átívelő kapcsolati hálók, kormányzati kapcsolatok, médiakapcsolatok stb. teszik esélyessé a tudóst.

\section{A folyóiratok}

III.A) Folyóiratok, könyvsorozatok „birtoklása”, azaz azok felügyelőbizottságaiban szerkesztőbizottságaiban, szerkesztőségeiben betöltött irányító pozíciók, rovatvezetések a tudományos mező müködésének fontos sajátossága, hiszen a publikációk megjelenésének befolyásolása munkáltatói jogosítványok és pénzforrások feletti diszponálás nélkül is befolyást biztosít a tudományos felemelkedés folyamatára. E jelenségnek több altípusa van.

III.A)1. Azok a tudományágak, ahol egyetlen domináns folyóirat van, ez esetben lényegében a folyóirat és könyvkiadásban semmiféle pozícióban nem rendelkező tudósokat állíthatjuk szembe a különböző erősségű pozíciók (tanácsadó tag, szerkesztő bizottsági tag, szerkesztőségi tag, rovatvezető, főszerkesztő) betöltőivel, lényegében skálaszerűen.

III.A)2. Vannak tudományágak, ahol több központi folyóirat, ill. könyvsorozat van - egyik általában az akadémiai bizottsághoz, másik az évszázados múltú országos tudományos társasághoz kötődik, tipikusan ilyen a történettudomány is. Itt már több változóval leírható, többdimenziós teret kell ábrázolunk, ahol az előző esethez hasonlóan szerepet játszik az egyes pozíciók fontossága az egyes folyóiratok, könyvsorozatok döntési folyamataiban, szerepet játszik, hogy egy tudós csak egyik vagy több folyóirat/ könyvsorozat döntéshozatalában vesz részt, s végül szerepet játszik, hogy a döntéshozatali tagságot azzal magyarázzuk-e, hogy az egyes folyóiratok, könyvsorozatok kiadásában szerepet játszó intézményben tölt be a tudós munkavállalóként, vezetőként fontos funkciót, vagy az „utcáról” kapott-e meghívást, személyes tekintélye alapján.

III.A)3. Vannak tudományágak, ahol egy vagy több központi folyóirat több évtizedes létezése után egy alterület vagy egy paradigma képviselői döntenek úgy, hogy új folyóiratot, új könyvsorozatot alapítanak. (Így alakult meg pl. a Világtörténet vagy az Agrártörténeti Szemle.) Ilyen esetben fokozottan vizsgálni kell, hogy az új folyóirat döntéshozói olyanok közül kerülnek-e ki, akik korábban nem voltak döntéshozók, vagy a döntéshozók egy csoportja szakadt le, esetleg egyesek leszakadtak, mások multipozicionálisak lettek. Igen fontos kérdés, hogy az új folyóirat a paradigma vagy alterület teljes körét magához vonzza, vagy maradnak olyanok, akik inkább a nagyobb múltú folyóiratban való kisebb részvételt, mint az új folyóirat teljes ellenőrzését tekintik hasznosnak.

III.A)4. Vannak tudományágak, ahol intézményi, ill. regionális folyóiratok is beindultak. Ezek szerkesztőbizottságaiban egyfajta látszólagos interdiszciplinaritás érvényesül, azaz helyben tekintélyes emberek szomszédos tudományterületekröl meghívást kapnak. Ez azonban a legritkább esetben vezet interdiszciplináris vagy multidiszciplináris szemléletű tanulmányokhoz, inkább ahhoz, hogy egy - vagy több - tudományág központi folyóiratának szintjét meg nem ütő, vagy a központi lap terjedelmi korlátait meghaladó tanulmányok fogadtatnak el. A lokális publikációk nagyszámú feltűnése már az 1960-as években arra késztette a történettudomány központi csoportjait, hogy úgy a tudomá- 
nyos fokozatszerzés témaválasztási lehetőségét, mint a beszámítható publikációkat valamiképpen korlátozzák - konkrétan az általánosítható tanulság nélküli, adatközlő jellegü helytörténeti munkákra specializálódott (vagy ellenfeleik által ilyeneknek minősített) tudósok, helyi értelmiségiek tudományos érvényesülési lehetőségeit korlátozzák.

III.A)5. Végezetül a 80-as évek második felétől a politikai állásfoglalás különbözősége is legitimációt teremtett újabb folyóiratok és könyvsorozatok alapítására. A rendszerváltás és a rendszerváltást követő három évtized a történettudományt „irányító” tudománypolitikai megfontolások mellett önálló tényezővé tette az emlékezetpolitika "nagyüzemi” működtetését, ahol az egyes álláspontokat alátámasztó történettudományi műveket legitimálásnövelés céljából is - mind gyakrabban sorozatjelleggel adják ki.

III.B) A tudományos népesség többsége nem vezet, nem irányít tudományos folyóiratokat vagy könyvsorozatokat, de használja őket publikációs fórumként.

III.B.1. Nyilvánvaló, hogy ennek a „használatnak” többféle módja lehetséges, hiszen egy publikálásra benyújtott tanulmány lehet adataiban, tanulságaiban teljesen vagy részlegesen új, s lehet korábban másutt már felhasznált adatok és tanulságok megismétlése, részben szövegszerüen vagy csak tartalmában - ha ismétlésről van szó, akkor a módosulás lehet lényegi (a folyóirat - eredeti közlési helytől eltérő - profilját, irányultságát tiszteletben tartó) és lehet minimális.

III.B)2. A publikáció puszta tényével (ill. ezen belül a fentiekkel) a szerző kifejez valamiféle kötődést a folyóirat érdekköréhez, ha „rangos” szerzőről van szó, akkor nevének felbukkanása a szerzők között megemeli a lap presztízsét. Mivel azonban egy tudományágban sem egyetlen hierarchia van, a szerző elsősorban - vagy kizárólag - azok szemében emeli meg a folyóirat presztízsét, akiknek szemében ő fontos szerzőnek számít.

III.B)3. Mindez fordítva is igaz, a publikáció befogadásával a folyóirat kifejezi nyitottságát azon tudóscsoport felé, amelyet a szerző „képvisel”. (Vagy ha nem is „képvisel”, de amihez a szélesebb szakma percepciója szerint „tartozik”.)

III.B)4. Ellentétben a szerkesztőbizottsági tagok, tanszéki alkalmazottak személyének kiválasztásával és kiválasztódásával, mely mindig szisztematikus, egy-egy tanulmány megjelenése olyan pillanatnyi körülményekkel is összefügghet, melyek esetlegesek (pl. „cikkhiány”, kommunikációs nehézség, elhamarkodott ígéret stb.) vagy nem esetlegesek ugyan, de a megjelenést követő néhány hónapon belül már elveszítik jelentőségüket (pl. valamely pénzösszeg kutatási elköltését legitimáló „disszemináció”, „álpublikáció”). Egy-egy folyóirat szerzői körét távolról figyelő - egy-egy közlés valódi motivációjával tisztában nem lévő - szakmabéli tehát könnyen eshet téves interpretáció áldozatául, melynek eredményeképpen a szerkesztőbizottság számára is váratlan kéziratok érkezése következhet, melyeket visszautasítani kínos lehet - azaz egy téves értelmezésből lassan laposodó publikációs hullámok keletkezhetnek, melyek az egyes folyóiratok tiszta érdekcsoportként való értelmezését a kortárs és történeti elemző számára egyaránt megnehezítik. 
III.C) A rendszer működését elemző kutató számára különösen kedvező eset, amikor a folyóiratokat kifejezett vitára használják. Ez esetben ugyanis a rendszer szereplőiben tudatosult és a szakmai nyilvánossággal tudatositani kívánt ellentétről van szó, s igen fontos, hogy a témák és paradigmák egymás mellett élését funkcionalista módon szemlélők is kénytelenek - legalábbis átmenetileg - konfliktusos paradigmában értelmezni az olvasottakat. (A funkcionalisták ugyanis a témahangsúlyok és megközelítésmódok közötti különbségeket egyfajta munkamegosztással magyarázzák.)

III.C)1. A vita egyik fajtája, amikor a szerkesztőbizottság vagy annak egy része érzékeli, hogy a tanulmány tanulsága, nyelvezete vagy bizonyító apparátusa a tudományág körében szokásostól eltér, ez esetben az írás eleve vitacikként jelenik meg.

III.C)2. A vitacikként megjelenítés külön esete, amikor szerkesztőségi kommentárral jelenik meg a cikk, illetve a szerkesztőség eleve felkér valakit, hogy még ugyanabban a számban reagáljon az írásra.

III.C)3. Más esetben a szerkesztőség által előre nem látott módon vált ki egy tanulmány vitacikket, ennek közlése vagy nem közlése más típusú vitákat gerjeszt minden szerkesztőségben, mint az eredeti tanulmányok közlése. A beérkező vitacikkek teljes vagy részleges közlése a szerkesztőbizottságon belül lehetőséget teremt a "megkérdőjelezhetetlenséghez", illetve a "nyilvános szabad vitához" füződő habituális különbségek és eltérő érdekek normál tanulmányközléseket meghaladó mértékü megjelenítésére. Ennek objektivációja, hogy több visszaemlékezés is alátámasztja: a vitacikkek közlése intenzívebb szerkesztőségi vitákat vált ki.

III.C)4. A szerkesztőség külön döntése, hogy viszontválaszra, illetve több számon áthúzódó vitára fogalmaz-e meg felhívást, illetve engedi-e annak kibontakozását. A döntés motívuma a vitában részt vevők súlya a szerkesztőbizottság vagy szerkesztőség tagjai szemében - s mivel ezt sokan így is gondolják, egyben ennek a "súlynak” a jelzésére is alkalmas a szélesebb szakmai közvélemény számára. A nagyobb tudományágakban, ahol tematikusan nagyon megosztott szakterületek (pl. középkortörténet, legújabbkortörténet stb.) alakulnak ki, a tudományágbeliek jelentős része csak a vitákból értesül egy távolabbi szakterületen ismeretes véleménykülönbségekről.

III. D) A folyóiratokat ritkább esetben „lektorként” is lehet használni. A lektori felkérés gyakoribb vagy ritkább visszautasításával a kutató által befolyásolható, hogy a szerkesztőség meghatározott tudományághoz, témához tartozó tanulmány lektoraként kisebb vagy nagyobb valószínűséggel kéri fel őt a későbbiekben. Ezzel szerkesztőbizottsági tisztség nélkül érdemben befolyásolható, hogy egy konkrét témakörben milyen tanulmányok jelenhetnek meg, ráadásul az írás és lektorálás névtelensége ellenére a bírált tanulmányok a lektori vélemények érveléséből neves szerzők gyakran egymásra ismernek - a sok lektorálást vállaló személy szisztematikusan kiterjesztheti szövetségi kapcsolatrendszerét. (A lektorok személyét - éves összesítésben - némely folyóirat s szinte minden szakkönyv közli.) 
III.E) A folyóiratok tematikus számainak „szerkesztődése” egy alkalmi mikrohálózat megteremtését jelenti. A főszerkesztő/szerkesztőség/szerkesztőbizottság erőviszonyrendszerébe belép a tematikus szám szerkesztője, akinek szerepe „aránytalanul” nagy - és akinek szakmai életében általában szintén „aránytalanul nagy” szerepet tölt be a tematikus szám szerkesztése. A szerzők kiválasztása, a témák elosztása, határvonal meghúzása, s a keletkező átfedések kihúzása vagy ki nem húzása jelentik azt a témavilágot, amit persze elsősorban részt vevő megfigyelőként lehet kutatni.

\section{Reflexiók}

IV.A) Majdnem a vitához mérhetően használható a könyvismertetés, könyvkritika, ennek összes elképzelhető mérőeszközével.

IV.A)1. A kritika mozzanatát jól le lehet írni a „felkért recenzens” és „jelentkező recenzens" szerepalternatívával, ami csak folyóirat-szerkesztőségen belülről figyelhető meg, melynek sajátos alesete, hogyha a kutató a felkérést elfogadja, majd feladatai között szisztematikusan hátrébb sorolja, halogatja az írást.

IV.A)2. Jellemezni lehet a kritika funkcióját az „ismertető kritika” és az „érdemben méltató/bíráló kritika" kettősséggel, ami az írások komplex kutatói megítélésével dönthető el.

IV.A)3. Jellemezni lehet azt a gyengeség, ill. kiválóság skálaszerűségével, ami részben jelzőkben, részben hazai és külföldi pályatársakkal való összehasonlítás révén történik meg - tehát ezek számbevételével kutatható.

IV.A)4. Jellemezni lehet azt a méret, illetve relatív teljesség érzékeltetésével, ami részben jelzőkben, részben a potenciális források lefedettségének megállapításában érhető tetten. A skála negatív végpontjaként azok a kritikák sorolhatók be, melyek tételes hiányosságokat sorolnak fel.

IV.B) Klasszikus, sokat vizsgált hálózati elem az idézet, mellyel kapcsolatban sok minden külön elemzendő:

IV.B)1. Hossza, önállósága, gyakorisága, szó szerintisége, egy szövegen belüli - nyomatékosító funkciójú - ismétlődése, szakkifejezés átvétele.

IV.B)2. Valamely mü szerzőre tett kifejezett hatásának szövegben történő megemlítése. Ezzel a meghivatkozott személlyel való kapcsolat nélkül is pozicionálhatja magát a szerző.

IV.B)3. Köszönetmondás (konkrét pályatársnak) adatokért, előzetes olvasásért, tanácsadásért. A köszönetmondás egyben arról is informálja az olvasót: kivel van olyan kapcsolatban a szerző, hogy efféle szívességet kérhet tőle. 
IV.B)4. Nem egy-egy szerzőhöz, de egy-egy érdekkörhöz kapcsolják a szerzőt azok a hivatkozások, melyek elemi tények, tudományos közhelyek alátámasztása céljából egyik vagy másik standard kézikönyvet neveznek meg, akkor is, ha maga a kézikönyv régi, távoli érdekkörhöz kötődik.

IV.B)5. Tartalmilag nyilvánvalóan inadekvát, szövegösszefüggésbe nem illő idézet, melynek egyetlen célja az idézett személy idézettségének növelése. Az inadekvát idézet lehet egy rejtett üzenet is, amelyben a szerző azt kommunikálja az olvasóval vagy az utókorral, hogy kizárólag az ideológiai elvárásoknak, tudománypolitikai erőviszonyoknak, munkahelyi kényszereknek köszönhető az idézet felbukkanása. A történettudományban ez inkább a korábbi évtizedekben volt jellemző, Marx-, Engels-, Lenin- és Sztálinidézés, illetve szovjet szerzők idézése formájában.

\section{Társszerzőség}

A hálózatkutatásban az egyik leggyakrabban kutatott téma a többszerzős művek megjelenése, mely az orvostudományban, természettudományokban nagyon gyakori, s a közgazdaságtudományban, szociológiában is növekvő arányt jelent.

A többszerzősségnek alapvetően három motivációját különböztethetjük meg:

V.A) A közös adatgyüjtésekből, közösen (munkamegosztással, forrásegyesítéssel) létrehozott adatbázisokból következő többszerzősség. Ennek motivációja lehet a más témákkal, más szerzőcsoportokkal való versengés is, az a feltevés, hogy egy-egy rangos folyóiratba bekerülni inkább lehet szerzőtársként, mint külön-külön tanulmányokkal pályázva. Lehet oka tényleges közös gondolkodás is. Ez a típus inkább a fiatal kutatókat jellemzi.

V.B) A másik fajta többszerzősség a szövetségi politika „kinyilvánítására” való. Biztos jele ennek, hogyha valakik rendszeresen együtt dolgoznak, másokkal pedig, akikkel pedig a téma közössége (melynek objektivációja pl. az azonos tárgyszó a könyvtári katalógusban) indokolná, sosem jelennek meg társszerzőként. Ennek a fajta szövetségi politikának igen gyakran „tudományon kívüli” okai vannak, azonos régióból származás, közös szocializációs élmények (pl. szovjet ösztöndíj...), népi-urbánus erőtérben való önpozícionálás, házastársi viszony, párkapcsolat stb.

V.C) A harmadik fajta többszerzősség, a mester-tanítvány, főnök-beosztott közötti kvázi kliensi viszony dokumentálására való. Ez éppúgy jelentheti tanítványok megjutalmazását, amikor kizárólag technikai munkát végző asszisztensségükért társszerzőséget „kapnak”, mint az ellenkezőjét, azaz, hogy a fiatalabb kutató hálából vagy munkahelyi normákat követve kényszerűségből vesz be szerzőnek tényleges munkát a tanulmányban nem végzö fönököket, idős mestereket stb. 


\section{VI. „Civil” szervezetek}

A tudományszociológia fontos kérdése a tudományos társaságok „birtoklása” - azaz a tudományos társaságok különböző szintű irányító pozícióiban történő elhelyezkedés, illetve a konkurrens tudományos társaságokban való részvétel.

VI.A)1. Az irányító pozícióknál külön elemzést érdemelnek az operatív (munkával járó) és a szimbolikus társasági funkciók. Ennek elemzését ugyanakkor nehezíti, hogy számos vezető tudós saját tevékeny habitusához igazítja a korábbi ciklusokban inkább reprezentatív jellegü pozíciót.

VI.A)2. A társaságokon belül csoportok, alcsoportok, szakosztályok, specializálódott munkabizottságok létrehozása - nagyjából hasonlóan a folyóiratokon belüli rovatok és alkalmi rovatok létrehozásához - irányító pozíciókat hoz létre, ugyanakkor az elszigetelődés, fragmentálódás kockázatát hordozza.

VI.A)3. Új tudományos társaságok létrehozásakor a kezdeményezőknek szinte azonos dilemmái vannak, mint amelyeket feljebb az új folyóiratok megteremtése kapcsán tárgyaltunk.

VI.A)4. A tudományos társaságok tevékenységekor hálózati kompromisszumok tárgya két fontos kérdés: az éves konferenciák fó témáinak meghatározása, s az országosan rangos konferenciák éves konferenciái rendezési jogának megszerzésére irányuló - intézmények közötti - versengés eldöntése. Az utóbbi kérdésbe gyakran tudományágon kívüli szempontok is belejátszhatnak, például ha egy-egy egyetem vezetői, egy-egy város vezetői, vagy helyi vállalkozók ambicionálják, hogy a számukra szakmailag érdektelen, de településüknek, intézményüknek országos nyilvánosságot biztosító konferencia rendezési jogát megszerezzék, s ehhez anyagi erőforrásokat is meg tudnak mozdítani.

VI.B) Ahogy a munkahelyek és folyóiratok esetében is célszerű volt szétválasztani az irányító pozíciókat és az „egyszerü részt vevő” kutatókat, a tudományos társaságok „használata” esetében is külön kell megjeleníteni, mire használhatja a vezető pozíció nélküli részt vevő tagság a tudományos társaságok intézményes viszonyait - tulajdonképpen mindegyik használati mód arra való, hogy pozícionálja magát a szaktudományos mezőben.

VI.B)1. Minden tudós választ a tudományos társaságok között, melyiknek kíván tagja lenni, s melyiknek nem. Amikor - pártállami viszonyok között - egy tudományághoz egy társaság tartozott, a tudósok szomszédos tudományterületek társaságainak (és persze folyóiratainak, könyvsorozatainak) választásával jelenítették meg mozgásterüket. Történészek számára például - választott kutatási területük függvényében - a Szociológiai Társaság, Irodalomtörténeti Társaság, Ókortudományi Társaság - jelentettek ilyen alternatívát. (A felszabadulás utáni évek magyar történetírása 1980; Ágh 1973; Bell 1992; Berényi 2010; Hacohen 2003; Hartmann 2006; Durst 2015; Mayer 2004; Rojas 2013; Somogyi 1988.) 
VI.B)2. A tudós választ tudományos társaságok szakosztályai, alcsoportjai között, melyiknek kíván tagja lenni, s melyiknek nem, megjelenítve ezzel nemcsak a szakosztály-alcsoport témavilága iránti érdeklődést, hanem azt is, hogy a szakosztályalcsoport vezetését valamennyire legitimnek ismeri el. Ha nem ismeri el legitimnek a vezetést, akkor egy másik szakosztályalcsoport keretében fogja ugyanazt a témát müvelni.

VI.B)3. A tudós jelen van (vagy nincs jelen) egyes társasági üléseken, engedi, hogy e tényt jegyzőkönyv vagy videofelvétel dokumentálja. Ez az aktivitás akár nagyobb önpozicionáló erővel is rendelkezhet, mint a munkahelyválasztás vagy munkahelyi feladatok (pl. konkrét órák) elvállalása, hiszen az utóbbiaknál a tudós megélhetési kényszerre hivatkozhat saját referenciacsoportjában - az üléseken való részvétel viszont önkéntes. A jelenlét gesztus is lehet periférikus intézményekben megrendezett konferenciák esetén, vagy akkor, ha ehhez messzire kell utazni, szállást kell fizetni stb.

VI.B)4. A tudós előadást tart a társaság konferenciáján, illetve hozzászól mások előadásaihoz - akkor is, ha ennek célja a tudományos tárgy felől nem ragadható meg, viszont az aktív jelenlét a tudós láthatóságát s ezzel a csoporthoz, a tömörüléshez tartozás láthatóságát biztosítja. A tudományos konferenciák vitaideje egészen sajátos lehetőségeket hordoz, kifejthetik véleményüket olyanok is, akiket a tudományterület domináns képviselői nem hívnak meg előadónak, nem engednek publikálni, nem tartanak komoly tudósnak. Kezdő kutatók fönökük engedélye nélkül nyilvánossághoz juthatnak. A publikációval ellentétben, mely ha meg is jelenik, nem feltétlenül olvassák azt el vezető kutatók, a konferenciavita élethelyzetében egy egyetemi hallgató is „kikényszerítheti”, hogy akadémikusok meghallgassák.

VI.C) Mindezek az aktivitások lehetségesek a szélesebb értelemben vett szakmai halmaz olyan tagjai számára is, akik nem rendelkeznek olyan tudományos fokozattal, ami a tudományos állások betöltésének formális feltétele, akiknek nem jut hely a tudományos intézményrendszerben, akik nyugdíjasként kiszorulnak onnét, akik politikai vagy tudománypolitikai konfliktusok eredményeképpen jövedelemszerző tevékenységet nem folytathatnak a tudományos mezőben stb. (A tudományos társaságokból való kizárás csak a legkeményebb diktatúrák viszonyai között fordul elő, sokkal később, minthogy az állások, illetve publikációs lehetőségek bezáródnak a másképp gondolkodók előtt).

\section{Egyéb hatalmi hálózatok}

VII.A) A kutatási pénzosztás, ösztöndíjosztás, kiadástámogatás mozzanatai - hatalmi aktusok -, s minél szerényebb a tudósok és egyetemi oktatók normál bérezése, s minél inkább elvárás egy tudományterületen a személyes munkaidőben nem, csak megbízottakkal megvalósítható kutatás, illetve minél gyakoribb, hogy szakmailag elismert kutatók nem töltenek be formális vezető pozíciót, annál nagyobb a jelentőségük.

VII.A)1. A döntéshozó testületek tagsága (mely gyakran állami kinevezésen múlik, semmiképpen nem egyszerű tükre a korábban jelzett elitpozícióknak) természetes nyilvános hatalmi pozíció. 
VII.A)2. Kevésbé nyilvános pozíció, hogy kiknek az ajánlása valószínűsíti valamely kutatási pénz, ösztöndíj stb. odaítélését.

VII.A)3. A döntések történetileg is rekonstruálható nyilvánossága miatt a tudományos közösség tagjai e vonatkozásban ismerik és számon tartják, kinek javul és kinek romlik a pozíciója az időtengely mentén. A tudományszociológust a kutatástámogatási öszszegek összehasonlítása formálisan azonos pozíciójú kutatók közötti előnyösebb, hátrányosabb helyzetű és egyáltalán nem támogatott kutatók megkülönböztetésére teszi képessé. A piaci vagy művészeti mező hierarchiáival ellentétben a tudományos életpályán való visszalépés objektiválása nem könnyü, hiszen ha politikai vagy tudománypolitikai okokból valaki elért egy olyan egyetemi tanári állást, ami a szokásosnál több ellenérzést szült a szakmában, az őt támogató politikai és tudománypolitikai körülmények elmúlása csak rendkívüli esetben vezet állásvesztéshez - viszont statisztikailag is konstatálhatjuk, hogy magas formális pozíció ellenére kevesebb pénzt kap valaki, mint abban az évtizedben, amikor őt támogató politikai vagy tudománypolitikai erők voltak hatalmon.

VII.B) Nem tudományos kitüntetések tudományos érdemekért történő osztogatásának befolyásolása (Kossuth-díj, Állami Díj stb.) fontos hatalmi pozíció.

VII.C) Nem tudományos adatok tudományos célokra történő átadása valódi hatalomgyakorlás- s természetesen azok is pozícióban vannak, akikről egyik-másik szakmában valamiképpen elterjed, hogy az átadás / át nem adás kérdésében nem tudományos tényezőknél tanácsadói, döntéselőkészítői pozícióval rendelkeznek.

VII.C)1. Ennek fontos altípusa az irattári, levéltári adatok átadása feletti uralom különösen, hogyha az átadás / át nem adás jogszabály által kevéssé rendezett, személyi mérlegelésen alapszik. Minősített eset, amikor az adat puszta létezése sem nyilvános azaz az adatbirtokos már azzal is gesztust tesz szakmai szövetségeseinek, hogy az adat létezésére, megkérvényezhetőségére felhívja a figyelmüket.

VII.C)2. Fontos altípus a meglévő - közpénzekből készített - statisztikai adatok átadása feletti uralom, ill. statisztikai adatgyüjtések tárgyának megszabása, kérdések kialakítása feletti uralom. Ez történészek számára is fontos lehet, hiszen idősebb embereknek feltett népszámlálási kérdések akár fél évszázaddal korábbi iskolázási vagy foglalkozási viszonyokról hozhatnak adatokat.

VII.C)3. Fontos altípus a közvélemény-kutató, piackutató cégek piaci értelemben már elavult, de tudományosan még használható adatbázisainak átadása feletti uralom.

VII.C)4. Fontos altípus - különösen abban a korszakban, amikor már sokan átlátják a digitális szöveghasználat előnyeit, de még sok folyóirat nincs az interneten - az interneten nem hozzáférhető, de szerkesztőségekben, kiadóknál, magánszemélyeknél hozzáférhető szövegtömegek átadása feletti uralom. E tanulmány írásakor pl. a fizetős és ingyenes portálokon a magyar könyvek és periodikák több tízmillió oldalához lehetett hozzájutni, de az elmúlt évtizedek talán legfontosabb kézikönyve (a Magyar nagylexi- 
kon) és legfontosabb hetilapjának (HVG) szövegfile-jai csak személyes szívességek segítségével voltak elérhetőek. A szövegbankok hozzáférhetőségének hatalmi mozzanatát ugyanakkor folyamatosan mérsékli a WEB2 hatás - az ízlésítélet vagy önérvényesítés, önreprezentáció által motivált szkennelő, digitalizáló - legális és „illegális”, mármint torrentező civil tevékenység.

VII.C)5. Személyes emlékek - szóbeli vagy levélben történő - átadása, át nem adása egyik vagy másik kolléga céljára szintén hatalomgyakorlás. A lejegyezni engedett emlékek felhasználásának engedélyezése és tiltása is az.

\section{Zárásul}

Láthattuk, hogy a tudományos hatalomérvényesítés rendszere majdnem minden vonatkozásban körkörös természetü:

- objektivációkkal kitüntetnek tudósokat, állásokkal, publikációs lehetőségekkel domborítják ki az azok felett diszponálók, hogy kik emelkednek ki a tudósok közül;

- a tudományos közvélemény (és nem tudományos közvélemény) szemében kiemelkedő tudósok az objektivációk, állások, publikációlehetőségek elfogadásával emelik ezeknek az objektivációknak, állásoknak, publikációs helyszíneknek a presztízsét - különös tekintettel azokra a helyzetekre, amikor többféle objektiváció jelzései között tévelyeg a megfigyelö, illetve amikor valamely objektiváció tekintélye - erősen megkérdőjelezhető személyeknek történő kiosztatása révén - korábban némileg megingott;

- a neves tudósok a különböző kiemelkedési módok legitimitását különbözőnek tartják, de a kiemelési mechanizmusokban való részvétellel növelik az egész rendszer legitimitását - azaz erősítik azt a tudást, illetve benyomást a rendszerben részt vevők és kívülről figyelők között, hogy hierarchizált és tagolt rendszerről van szó, melyben nem - sportversenyeredményhez vagy alkalmi üzleti döntéshez hasonló - egyszeri teljesítmény, hanem valamiféle szisztematikus, évtizedes tevékenység számít.

E körkörösség azt is jelenti, hogy nemcsak azon a módon művelhetünk tudományszociológiát, hogy előre definiáljuk a vizsgált tudományágak határait, a tudományos elismertség kritériumait vagy a tudományos témák listáját, hanem úgy is, hogy iteratív módon, magából az elemzésből - annak éppen befejezett fázisából - formáljuk újra a határokat, a kritériumokat, a listákat. Dinamikusan értelmezzük az „irányítók és a „használók” viselkedésmódját, hol úgy értelmezve az irányítói és használói szerepkört, mely egyértelmüen hozzákötődik valakikhez, hol azt hangsúlyozva, hogy az irányítás, ill. használat maga alakítja ki a kötődést. Mindezzel talán jobban megértve a társadalomtudományok müködő valóságát, mint amennyire ezt a klasszikus kvalitatív, illetve kvantitatív megközelítések képesek.

\section{IRODALOM}

A felszabadulás utáni évek magyar történetírása (1980) Rövid áttekintés. (Az 1980-ban Bukarestben rendezett kongresszusra készült tanulmánykötetben megjelent beszámoló magyar nyelvű változata.) Századok, Vol. 114. No. 3. pp. 331-508. 
Ágr A. (1973) Az östörténet aktualitása: a marxista östörténet-elmélet fejlödésébez. Budapest, Kossuth Könyvkiadó.

Aronowitz, St. (1988) Science as Power: Discourse and Ideology in Modern Society. Minneapolis, University of Minnesota Press.

Barabási A. L. (2003) Bebálózva. Budapest, Magyar Könyvklub.

Barnes, B., Bloor, D. \& Henry, J. (2002) A tudományos tudás szociológiai elemzése. (Ford. Faragó Péter és Tanács János.) Budapest, Osiris Kiadó.

Bell, R. (1992) Impure Science: Fraud, Compromise and Political Influence in Scientific Research. New York, Chichester, John Wiley \& Sons Ltd.

Berényi D. (2010) A tudomány és a világ különböző kultúrái. Magyar Tudomány, No. 6. p. 698.

Bourdieu, P. (1988) Homo academicus. Transl. by Peter Collier. Cambridge, Polity Press.

Bourdieu, P. (2005) A tudomány tudománya és a reflexivitás: a College de France 2000-2001. évi elöadás-sorozata. Ford. Házas Nikoletta, Simon Vanda. Budapest, Gondolat.

Braun T., Glänzel W. \& Schubert A. (1992) Országok, szakterületek, folyóiratok tudománymetriai mutatószámai: 1981-1985. Budapest, Magyar Tudományos Akadémia.

Csomós Gy. (2019) A kelet-közép-európai országok publikációs kibocsátásai és nemzetközi együttmüködései: trendek és változások 1997 és 2016 között. Tér és Társadalom, Vol. 33. No. 3. pp. 127-149.

Dupcsık Cs. (2001) A reflexivitás a tudományos ismeretek szociológiájában. Budapest, Osiris.

Durst, J. (2015) Lost mission or interdisciplinary realignment? [elektronikus dokumentum]: The plight of sociology and the role of the sociologist from the (semi-)periphery: interview with Zsuzsa Ferge, Miklós Hadas and Iván Szelényi / by Judit Durst; transl. by Zsuzsa Árendás. Intersections [elektronikus dokumentum], Vol. 1. No. 2. pp. 113133.

Farkas, J. (1991) A Sociological Analysis of Science and Technology. Erlangen, [S. n.]

Fortescue, St. (1990) Science Policy in the Soviet Union. London, New York, Routledge and Kegan Paul.

Gagyi Á. (2015) A Moment of Political Critique by Reform Economists in Late Socialist Hungary [elektronikus dokumentum]: 'Change and Reform' and the Financial Research Institute in Context. [A tematikus szám címe: Making Sense of Difference: Social Sciences in the Central and East European Semi-Periphery.] Intersections [elektronikus dokumentum], Vol. 1. No. 2. pp. 59-79.

Habermas, J. (1994) A társadalomtudományok logikája. Ford. Adamik Lajos et al. Budapest, Atlantisz Könyvkiadó.

Hacohen, M. (2003) Karl Popper. A liberális gondolat a tudományban és a politikában. Budapesti Könyvszemle, Vol. 15. No. 4. p. 364.

Hartmann, M. (2006) The Sociology of Elites. Routledge, New York.

Horváth P. (1997) A tudomány szabadságának történelmi szerepváltásai. Budapest, Mundus Magyar Egyetemi Kiadói Kft.

KarÁdy, V. \& NAgY, P. T. (2018) Institutionalization and Professionalization of the Social Sciences in Hungary Since 1945. In: Christian Fleck, Mattihias Duller, Victor Karády (eds) Shaping Human Science Disciplines. Socio-Historical Studies of the Social and Human Sciences. London, Shaping Human Science Disciplines Institutional Developments in Europe and Beyond. pp. 289-326. 
Kováts G. (2012) A tudományterületi sajátosságok következményei a kutatásban, az oktatásban és a felsőoktatási intézmények vezetésében. Vezetéstudomány, Vol. 43. Nos 7-8. pp. 3-17.

Kozma T. (1990) Kié az iskola? Edukáció Kiadó, Budapest.

Mayer, H. (2004) Egy tanulmány Robert K. Merton hagyatékából. Valóság, Vol. 47. No. 9. p. 125.

Merton, R. K. (1996): On Social Structure and Science. Ed. and with introd. by Piotr Sztompка. Chicago, London, University of Chicago Press.

PALló G. (2011) A tudományos siker kettős természete: fiatal kutatók és a siker. Magyar Tudomány, Vol. 172. No. 4. pp. 473-487.

PApp B. (2017) Szociológus a pszichiátrián: Kovai Melinda: Lélektan és politika: pszichotudományok a magyarországi államszocializmusban, 1945-1970. Korall, Vol. 18. No. 69. pp. 197-202.

Péteri Gy. (1998) Academia and State Socialism: Essays on the Political History of Academic Life in post-1945 Hungary and Eastern Europe. / Boulder: Social Science Monographs; Highland Lakes: Atlantic Research and Publications. New York, Columbia University Press.

Püsök I. (2018) Jó üzlet az antropológia? Az üzleti antropológia történeti, elméleti, módszertani és etikai felvetései. Replika, 106/107. pp. 147-163.

RÁcz M. (2018) Egy új kor alkonyán: a kritikai menedzsmentkutatás relevanciájáról. Replika, 106/107. pp. 9-24. https://www.replika.hu/replika/106-107-01 [Letöltve: 2021. 12. 10.]

Ringer, F. K. (1990) The Decline of the German Mandarins: The German Academic Community, 1890-1933. Hanover, London, Wesleyan University Press.

Rojas, C. A. A. (2013) Fernand Braudel és a társadalomtudományok. (Eszmélet kiskönyvtár.) Budapest.

Soмоgy F. (1988) A magyar közgazdaságtan helyzete a nyolcvanas években. Valóság, No. 4. p. 49.

Szabari V. (2010) A tudomány társadalmasítása. Replika, Vol. 21. No. 73. pp. 11-18.

Szelenyi, I. (2015) The Triple Crisis of Us Sociology. Global Dialogue [elektronikus dokumentum], Vol. 5. No. 2. http://globaldialogue.isa-sociology.org/the-triple-crisis-of-ussociology/ [Letöltve: 2021. 12.10.]

TAmÁs P. (2010) A krízis és a társadalomkutatás: ki miért felelős? Tudományszociológiai megfigyelések. In: A cselekvő értelmiségi. Tanulmányok Huszár Tibor 80. születésnapjára. [Budapest], Argumentum - ELTE Társadalomtudományi Kar. pp. 326-340.

TAMÁs P. (1980) A tudománypolitika modelljei. A tudománypolitika szociológiai vizsgálatának dilemmáiról. Budapest, Akadémiai Kiadó.

Vekerdi L. (1994) Tudás és tudomány. Budapest, Typotex Elektronikus Kiadó Kft.

A cikk a Creative Commons Attribution 4.0 International License (https://creativecommons.org/licenses/ by/4.0/) feltételei szerint publikált Open Access közlemény, melynek szellemében a cikk bármilyen médiumban szabadon felhasználható, megosztható és újraközölhető, feltéve, hogy az eredeti szerző és a közlés helye, illetve a CC License linkje és az esetlegesen végrehajtott módosítások feltüntetésre kerülnek. (SID_1) 